\title{
Who Play for the National Football Team of Montenegro, Montenegrins or "Montenegrins"?
}

\author{
Stevo Popovic ${ }^{1}$ \\ 'University of Montenegro, Faculty for Sport and Physical Education, Niksic, Montenegro
}

\begin{abstract}
The research question in this paper was set in order to answer the question of who is playing for the national football team of Montenegro, whether "modern Montenegrins" or "ethnic Montenegrins", that is, to try to explain in a practical way how the inhabitants of Montenegro should experience the nation, and how ethnicity. By analysing the current circumstances, it has been determined that for the national football team of Montenegro exclusively inhabitants can play, that is the citizens of Montenegro, regardless of their ethnicity, religion or some third affiliation at a lower level of value while ethnic Montenegrins from Diaspora cannot play for the national football team of Montenegro because they do not hold Montenegrin citizenship. Therefore, it is not difficult to conclude that only members of one nation can play for a national football team, and in the Montenegrin case, they are inhabitants, that is, citizens of Montenegro.
\end{abstract}

Key words: football, nation, national identity, ethnicity

\section{Introduction}

There is a lot of interest among the citizens of a country, both nationally and personally, for the success of their national teams. This success leads people to have the opportunity to empower national pride and belonging to the social group they belong to. Whether it is sports games, or individual sports, or any other competition, most sympathizer or fans of a particular team have a passion and a desire to win, and those feelings are the strongest when it comes to national teams. It is in the nature of a man to identify himself with the successes of the social group he belongs to; however, especially in the territory of the former Yugoslavia, but also in some other countries around the world, it is still not clearly demarcated to which national group they really belong, since, in certain social communities, a clear social attitude is not taken about what is a nation and what is ethnicity, and how citizens should experience these two well-known but very complex terms. Often, the term "religion" intertwines between the two aforementioned terms, and introduces even greater confusion in the definition of modern nations.
A large number of research questions are asked in order to answer the question considering which nation or ethnic group we belong to, while there are also a number of theories on nationalism that recommend approaches that will give meaningful answers and solve practical issues in this field; however, clear answers to the questions asked do not exist yet, as there is no consensus among the participants in the dialogue. Therefore, the author decided to set up a research question that refers to the fact who is playing for the national football team of Montenegro, and in a practical way he tries to clarify how the citizens of Montenegro should experience the nation, and how ethnicity, i.e. to offer a solution which would alleviate inter-ethnic intolerance and strengthen national identity and group cohesion in Montenegrin society at large.

\section{Nation and theories of nationalism}

In order to answer the raised research question, it is worth to start from defining the nation and understanding the theory of nationalism, which, from the theoretical point of view, is the answer to the raised research question. However, it is known

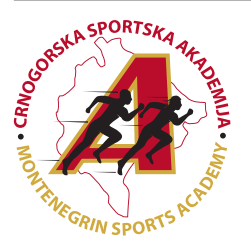

Correspondence:

S. Popovic

University of Montenegro, Faculty for Sport and Physical Education, Niksic, Montenegro

E-mail: stevop@ucg.ac.me 
that it is very difficult with "dry" theory to reach citizens and their stands, but the theory is necessary as a strong basis in the process of proving any scientific legality and, therefore, in the creation of social values. Furthermore, in order to deal with certain problems in practical ways, when it comes to the study of nations and nationalism, or one of their main products, a national identity in contemporary society, it is necessary to process available literature in this field. First, it should start from the fact that one nation, according to Popovic and Bjelica (2013), can be considered a group of people who share a genetic background and lives under the same conditions, i.e., possesses common and distinctive elements of culture, then has a unique economic system, an equal right to citizenship, have a sense of solidarity stemming from common experience and occupies a common territory, while the study of nationalism is spanned by using different terms to describe a similar or identical concept. Kellas (1998) has divided studies that have studied nationalism in two main approaches, primarily on instinctive and contextual, and then Cronin (1999) places them in primordialism, etatism, political mythology and modernism, while Smith (2001) divides them into perennialism, primordialism, etnosimbolism and modernism. Each of these approaches can be widely categorized, and contemporary authors agree that there is an ethnic and modernist approach in the study of nationalism (Popovic \& Bjelica, 2014). The differences that appear between these two approaches are based on views that differ in relation to the "birthday of the nation". Ethnic nationalists believe that nations existed even before the last decade of the 18th century, while modern nationalists recognize nations as the creation of the 18th and 19th centuries (Hastings, 1997). Therefore, it is very important for a Montenegrin circumstances to determine whether to accept first or the second approach. Ethnic nationalism offers the option that the Montenegrin nation consists exclusively of "ethnic Montenegrins", which according to the 2011 census do not exceed more than 50\% (Monstat, 2011), while modern nationalism binds nationality for citizenship, as in most European countries, and in that case the Montenegrin nation was made of all inhabitants, i.e. citizens of Montenegro, who could be called "modern Montenegrins". With the right approach, the creation of a national identity that would raise the level of cohesion among the citizens of Montenegro, would direct them to work together towards achieving goals for the benefit of the entire community. However, there is still an open question in Montenegro, and there is a lot of misunderstanding when talking about national and ethnic, and the clarification of these dilemmas, for which there is no clear social consensus, are of great social significance to be clarified.

\section{Who can play for the national football team of Monte- negro?}

Since football is the most popular sport in the world, and since every success of the national football team promotes national pride and its prestige internationally, provokes national pride and empowers national identity, it is no coincidence that for the needs of this study a national football team was taken as an example, because even the Montenegrins do not lag behind other countries of the world when we talk about love for football. Nevertheless, no one looks at the following questions, which, with proper analysis, could give important answers to a number of socially topical issues: who can play for the national football team of Montenegro, whether only those who feel like "ethnic Montenegrins", all those who have the citizenship of Montenegro, or those who do not have, or do not feel like Montenegrins? Can those who have, solely Montenegrin citizenship, play for another national football team or FIFA propositions do not allow it, or do those who feel "ethnic Montenegrins" and do not possess Montenegrin citizenship can play for the national football team of Montenegro? Let's start from the beginning. FIFA (FIFA, 2000) propositions clearly define that for the national team of a country exclusively citizens of that country can play, that is, those footballers who have the citizenship of that country. Therefore, for the national football team of Montenegro, only citizens of Montenegro, or all those who have Montenegrin citizenship, can play, regardless of how they feel considering ethnicity or religion, that is, any third social division. Also, for the Montenegrin national football team players who feel like ethnic Montenegrins, but do not have Montenegrin citizenship cannot play, which clearly tells us that those who consider themselves "ethnic Montenegrins" cannot play for the national team for example players from Diaspora, but only players who have Montenegrin citizenship. The same is the case with Montenegrin citizens of another ethnicity, who can play, exclusively for their national team, that is, for the national football team of Montenegro. Therefore, it is interesting to put emphasis on the word "national" in the construction of the "national football team", i.e. with the explanation of the name of the state team, pointing out to the fact that in daily communication, these terms are used which give us an answer to the question of what represents nation and ethnicity. By agreeing to the daily use of this term, the message of approach is clearly sent out when the dilemma considering theories about nationalism are concerned, that is, the modernist approach is widely applied in Montenegro. Therefore, it is important to point out that most of Montenegrin citizens do not mind that the national team is set of players that are the same nation, composed of players of different religious and ethnic backgrounds, as well as other minority groups. What does this mean in practical terms? This means that the nation is not represented by people with personal feelings about the biological background of their ancestors, but people who are citizens of one state, and that every citizen of Montenegro has the same right to participate in the national football team, in accordance with his football qualities, and independently of his race, ethnicity or religion, or any other diversity at the national level. Furthermore, it is worth pointing out that it is evident that a significant number of people, but also political leaders, although their political entities are called civil, still have resistance to the modernist approach; however, the question arises what is the basis of the above resistance: whether the blind monitoring of their political leaders who did not clearly and reasonably explained the possibilities of our choices, whether due to mere spite of one political party to another one, or from a third cause known to them. All in all, the fact is that a multi-ethnic and multi-confessional society, such as the Montenegrin, has a strong need to strive for the modern social trends of the modern world, in order to close the issues of separation and open issues of communion and development.

As there is a part of the citizens of Montenegro who oppose the modernist approach, there are other countries in the world where their citizens are also opposing contemporary and modern ideas, or striving for conservative approaches. If we take examples from the countries that are members of the European Union, which should be an example, since they are precisely 
the bearers of modern social values, the issue of the national identity in Spain, i.e. the strengthening of the identity of the ethnic group in one of the Spanish provinces, in Catalonia, then in Belgium, where there is still a strong conflict between the ethnically distinct Flemings and the Valonians, who, with a lot of bitterness, gather around the Belgian national flag. Such issues are noticeable in other countries outside the European Union, such as, for example, in Macedonia, that is, the part of the inhabitants of Macedonia who are ethnic Albanians, in Bosnia and Herzegovina, at the level of state entities, inhabited by citizens of the Orthodox, Catholic and Muslim religion, and also in China, or in Taiwan, where the islanders promote their specificity, but also in Turkey, which has a clearly established modernistic approach at the state level, however, in the Kurdish region where exists open issues of similar character, and this very strong state has not yet fully managed to integrate the mentioned ethnic group. All in all, these issues can be solved exclusively by state-level consensus; however, in many cases such a consensus represents an impossible mission.

\section{Conclusion and recommendations}

From all of the aforementioned, it is a fact that for the national football team of Montenegro exclusively citizens of Montenegro can play, that is, all those who pass the strict selection by the Football Association of Montenegro in all age categories of their national teams. In this way, we come to the conclusion that Montenegrins play for the national football team of Montenegro, that is, players who are in the first place Montenegrin citizens, i.e. they have a valid Montenegrin citizenship. Therefore, it is not wrong to conclude that the national team consists of the elected representatives of one nation or the Montenegrin nation in this case, regardless of their ethnicity, religion, or some third affiliation which makes them different from other citizens of their country. On the other hand, the question arises: what about the part of Montenegrins, that is, those who make the ethnic Montenegrin group, whether they should be the most important citizens or have any benefits in relation to other ethnic groups in the multi-ethnic and multi-confessional society like Montenegrin? Of course not, it would be wrong to offer any benefits to any ethnic group within a nation, as this would lead to the collapse of cohesion in society, that is, the interethnic intolerance would be heightened, which is not of interest to any of the ethnic or any other minority groups.

Nevertheless, despite clearly defined guidelines at the theoretical level, in Montenegrin society, in practical terms, the theory is still not accepted at an adequate level, we are witnesses of frequent falls at sports, especially football stadiums, which are aimed at rebuilding inter-ethnic and among-confessional intolerance. In order to adequately neutralize such extreme cases, which still do not have a wide application, social responsibili- ty is of great importance, primarily the academic community in Montenegro, then political subjects, especially those whose programs do not clearly define guidelines for clarifying these very important issues one independent state, as well as sports subjects, such as national associations, clubs and players, whose clearly defined messages can quickly reach the citizens of Montenegro and influence their attitudes and beliefs.

Finally, for the sake of a better future and a calmer life, reducing multi-ethnic and multi-confessional intolerance, and then raising social cohesion, which would allow us to focus more on socially topical issues for the purpose of economic development, we should appeal to all citizens of Montenegro, to accept the modernist approach to nationalism, which is widespread in developed countries in Europe and the world. We should agree with the fact that ethnic and religious, as well as any other specificity among Montenegrin citizens and members of the Montenegrin modern nation, should be cultivated at lower levels the level of significance within the family and members of minority groups, through various conferences and cultural programs, which the state should equally support in all its segments. Such an approach should be in the interest of all citizens, because it would save a lot of energy spent on ethnic, religious and other minority issues, which could be focused on current issues of interest to social prosperity and economic society development in which we all live and work together.

\section{Acknowledgements}

There are no acknowledgements.

\section{Conflict of Interest}

The authors declare that there are no conflicts of interest.

Received: 29 October 2018 | Accepted: 05 December 2018| Published: 01 February 2019

\section{References}

Cronin, M. (1999). Sport and Nationalism in Ireland, Gaelic Games. Soccer and Irish Identity since 1884. Dublin: Four Courts.

GOAL. (2018). FIFA national team eligibility: Rules, players who have switched \& everything you need to know. Retrived on 20 December 2018 from https://www.goal.com/en/news/fifa-national-team-eligibility-rules-players-who-have/1hndiedxd2d4h1jfved27pg4go

Hastings, A. (1997). The Construction of Nationhood. Ethnicity, Religion and Nationalism. Cambridge: Cambridge University Press.

Kellas, J. (1998). The politics of nationalism and ethnicity. London: Mac-millan. Monstat. (2011). Population of Montenegro by sex, type of settlement, etnicity, religion and mother tongue, per municipalities. Retrived on 12 July 2011 from http:// www.monstat.org/userfiles/file/popis2011/saopstenje/saopstenje.pdf

Popovic, S., \& Bjelica, D. (2013). Relationship between sport and national identity in Montenegro. Sport Mont, XI(37-38-39), 60-66.

Popovic, S., \& Bjelica, D. (2014). Do Significant Achievements of National Football Team Can Strengthen National Identity in Montenegro? Montenegrin Journal of Sports Science and Medicine, 3(1), 31-33.

Smith, A.D. (2001). Nationalism: Theory, Ideology, History. Cambridge: Polity Press. 